\title{
Analysis of Land Use of Pastoral and Agropastoral Zone of South East Niger: Case of Goudoumaria
}

\author{
Ado Salifou Hadiza ${ }^{1,2}$, Abarchi Idrissa ${ }^{3 *}$, Ambouta Karimou Harouna ${ }^{4}$ \\ and Yamba Boubacar ${ }^{2}$
}

${ }^{1}$ Département de Sociologie, Anthropologie, Economie et Communication, Institut Supérieur Environnement Ecologie, Université de Diffa, BP: 78, Diffa, Niger

${ }^{2}$ Département de Géographie, Faculté des lettres et Sciences Humaines, Université Abdou Moumouni de Niamey, BP: 10960, Niamey, Niger

${ }^{3}$ Département des Sciences du Sol et Télédétection, Faculté d'Agronomie et des Sciences de l'Environnement, Université Dan Dicko Dankoulodo de Maradi, BP: 465 Maradi, Niger

${ }^{4}$ Ressources Naturelles, Faculté des Sciences Agronomiques, Université de Tahoua, BP:255, Tahoua, Niger

*Corresponding author

\section{A B S T R A C T}

Keywords

Goudoumaria,

Ecosystems,

Agropastoral,

Pastoral, Land use,

Degradation of

fertile land

\section{Article Info}

Accepted:

12 September 2019

Available Online:

10 October 2019
Like in the arid and semiarid ecosystems, the northern limit of rainy season crops ecosystems have a dynamic influenced by harsh climatic condition. In addition to this, there is a high demand in goods and services by the over increasing population. The objective of the present study was to analyze land use in pastoral and agropastoral areas in the department of Goudoumaria, located in the South East of Niger. It is an agropastoral areas, where the practice and success of rural activities is based on physical conditions, the repartition and regularity of rainfall. Hence, many sites have been selected in the study areas and data has been collected from each site and analyzed. Results of land use mapping revealed a change in vegetal cover appearance and this lead to increase in degradation of fertile lands by remobilization of dunes previously fixed.

\section{Introduction}

Niger Republic is located in the earth of Sahel, between $11^{\circ} 37^{\prime}$ and $23^{\circ} 33^{\prime}$ North latitude and $16^{\circ}$ and $0^{\circ} 10^{\prime}$ East longitude. It is characterized by all types of arid and semiarid ecosystems and covers an area of $1267000 \mathrm{~km}^{2}$ among which 15 million hectares can be cultivated. However, only 6.5 million hectares are under cultivation (Projet- 
MEPRED-Niger, 2007). More than $80 \%$ of these potentials are composed of sandy soils which are generally fragile, poor in nutrients elements and organic matter, hence sensitive to wind and water erosion (Projet-MEPREDNiger, 2007).

The rainfall is characterized by high variability in time and space and the succession of drought since the beginning of nineteen seventies (Ozer et al., 2010).

Agricultural yields are low as soils are poor in organic matter and are exposed to wind throughout the year and the practice of irrigation is very limited (less than $2 \%$ of cultivated areas). Livestock rearing is prominent only in years of sufficient rainfall despite the fact that these are the two activities in the country.

The area of oasis "cuvettes" is also exposed to this phenomenon by the climatic variability and anthropogenic factors. The increasing livestock and population lives by exploiting natural resource of this area. However, in the second half of the $20^{\text {th }}$ century, the disappearance of forest was noticed at an alarming rate of $2 \%$ yearly (Ariori et al., 2005). Therefore, desert progression constitutes a major problem in the arid and semi-arid areas. Hence desert intensification is a great problem in arid and semi-arid regions.

It appears by the deterioration of land covers of soil and water resources. And with regards to the high demographic pressure, natural resources are endangered. However, authors stated that in Niger, compared to the 1970s, land degradation has been significantly reduced, erosion has been decreased, and soil fertility has been boosted and agricultural productivity enhanced through the practice of natural regeneration on 5 millions hectares since 2005 (Larwanou et al., 2006 ; Baggnian et al., 2013; Francis and Weston, 2015).
Thus, the objective of this study is the analysis of land use in Goudoumaria.

\section{Materials and Methods}

\section{Study site}

The study was conducted in the department of Goudoumaria located between $13^{\circ} 38^{\prime}$ and $14^{\circ} 09^{\prime}$ north latitude and $10^{\circ} 65^{\prime}$ and $11^{\circ} 26^{\prime}$ east longitude.

\section{Land use mapping}

Previous works have helped identified the model type based on whether you are approaching a "cuvette" or a village. Thus land use mapping was based on the current state by visual supervised classification based on color, forms, degree of vegetation cover validated by field surveys and information derived from climatological data, interview, etc. The different operations consisted of image processing (Table 1); the mosaicing of two scenes for each year, the extraction of the study area; the supervised classification and layout.

\section{Results and Discussion}

\section{Land use in 1986}

Analysis of the situation reveals that in 1986, trees and shrubs occupies more than half of the total area mapped in some locations, then the mosaic crop-shrubbs of interdunal corridors. This area was less populated as houses represent only $0.16 \%$ of the total area. Finally, the remaining areas were occupied by palm groves, cropping lands and dunes (Table 2, Figures 1 and 2).

\section{Land use in 1999}

For the situation of 1999 (Figure 3), there is a regression of trees and shrubs in favor of all 
other units particularly bright dunes and very little covered dunes. There is also a slight increase in human occupation and cultivated area (Table 3).

\section{Land use in 2010}

The 2010 situation is represented spatially by Figure 4. This period is marked by a resumption of steppe formation that increases in area. While those of all other units had regressed, except for housing zones which are widening by $0.21 \%$ (Table 4 ).

\section{Land use in 2014}

Finally, the analysis of 2014 situation (Figure 5), which is considered as the current state of ecosystems gives a breakdown of units with a small changes in the area of all units compared to the situation in 2010 (Table 5). In addition, this situation reveals a steppe regression of $12.78 \%$ in favor of dunes very little covered which will have more than double their surface area (with an increase of 112.48\%); the bright dunes will increase to $33.29 \%$ and the residential areas to $38.69 \%$. The areas occupied by palm groves or "cuvettes" will decrease by $2.92 \%$ (Figure 5 ).

Land use and soil utilization reflect human pressure on the ecosystems and their responses to the quality and quantity of services offered. In 1986, tree-shrub steppe and palm groves which constitute stable and covered units still occupied considerable areas. This period marks the end of the great drought of the $70 \mathrm{~s}$ and 80s.

Table.1 Characteristics of images used

\begin{tabular}{|c|c|c|c|c|c|}
\hline Images & date & $\begin{array}{c}\text { Spatial } \\
\text { resolution }\end{array}$ & $\begin{array}{c}\text { Temporal } \\
\text { resolution }\end{array}$ & Swath & $\begin{array}{c}\text { Spatialised } \\
\text { Parameters }\end{array}$ \\
\hline Lansat 5 & $07 / 10 / 1986$ & $30 \mathrm{~m}$ & 16 days & $180 * 180$ & Land use \\
\hline Landsat 5 & $19 / 10 / 1999$ & $30 \mathrm{~m}$ & 16 days & $180 * 180$ & Land use \\
\hline Landsat 7 & $13 / 04 / 2010$ & $30 \mathrm{~m}$ & 16 days & $180 * 180$ & Land use \\
\hline Landsat 8 & $17 / 10 / 2014$ & $30 \mathrm{~m}$ & 16 days & $180 * 180$ & Land use \\
\hline
\end{tabular}

Table.2 Distribution of land use units in 1986

\begin{tabular}{|l|c|c|}
\hline \multicolumn{1}{|c|}{ Land use units } & $\begin{array}{c}\text { Area in hectare } \\
\text { (ha) }\end{array}$ & Percentage (\%) \\
\hline Trees and/or shrubs by location & 177858.92 & 67.14 \\
\hline Very little bright dunes covered by location & 15031.76 & 5.67 \\
\hline Bright dunes & 15530 & 5.86 \\
\hline $\begin{array}{l}\text { Mosaic crops - trees-shrubs of interdunal } \\
\text { corridors }\end{array}$ & 34872.05 & 13.6 \\
\hline Cropping areas & 15045.05 & 5.68 \\
\hline Palm groves & 6182.83 & 2.33 \\
\hline Housing area $\quad$ Total & 415.69 & 0.16 \\
\hline \multicolumn{1}{|c|}{} & 264936.35 ha & 100 \\
\hline
\end{tabular}


Table.3 Distribution of land use units in 1999

\begin{tabular}{|c|c|c|}
\hline Land use units & Area in hectare (ha) & Percentage (\%) \\
\hline Trees and/or shrubs by location & 151608.98 & 57.22 \\
\hline $\begin{array}{c}\text { Very little bright dunes covered by } \\
\text { location }\end{array}$ & 27566.94 & 10.41 \\
\hline Bright dunes & 23344.91 & 8.81 \\
\hline $\begin{array}{c}\text { Mosaic crops - trees-shrubs of } \\
\text { interdunal corridors }\end{array}$ & 37204.57 & 14.04 \\
\hline Cropping areas & 18549.39 & 7 \\
\hline palm groves & 6189.72 & 2.34 \\
\hline Housing area & 471.84 & 0.18 \\
\hline Total & 264936.35 & 100 \\
\hline
\end{tabular}

Table.4 Distribution of land use units in 2010

\begin{tabular}{|c|c|c|}
\hline Land use units & Area in hectare (ha) & Percentage (\%) \\
\hline Trees and/or shrubs by location & 156738.86 & 59.16 \\
\hline $\begin{array}{c}\text { Very little bright dunes covered } \\
\text { by location }\end{array}$ & 30477.88 & 11,50 \\
\hline Bright dunes & 21570.66 & 8,14 \\
\hline $\begin{array}{c}\text { Mosaic crops - trees-shrubs of } \\
\text { interdunal corridors }\end{array}$ & 34478.08 & 13.01 \\
\hline Cropping areas & 15072.16 & 5.69 \\
\hline palm groves & 6050.97 & 2.28 \\
\hline Housing area & 547.74 & 0.21 \\
\hline Total & 264936.35 & 100 \\
\hline
\end{tabular}

Table.5 Distribution of land use units in 2014

\begin{tabular}{|c|c|c|}
\hline Land use units & Area in hectare (ha) & Percentage (\%) \\
\hline Trees and/or shrubs by location & 155119.37 & 58.55 \\
\hline $\begin{array}{c}\text { Very little bright dunes covered } \\
\text { by location }\end{array}$ & 31939.78 & 12.06 \\
\hline Bright dunes & 20701.10 & 7.81 \\
\hline $\begin{array}{c}\text { Mosaic crops - trees-shrubs of } \\
\text { interdunal corridors }\end{array}$ & 34904.36 & 13.17 \\
\hline Cropping areas & 15692.61 & 5.92 \\
\hline palm groves & 6002.60 & 2.27 \\
\hline Housing area & 576.53 & 0.22 \\
\hline Total & 264936.35 & 100 \\
\hline
\end{tabular}




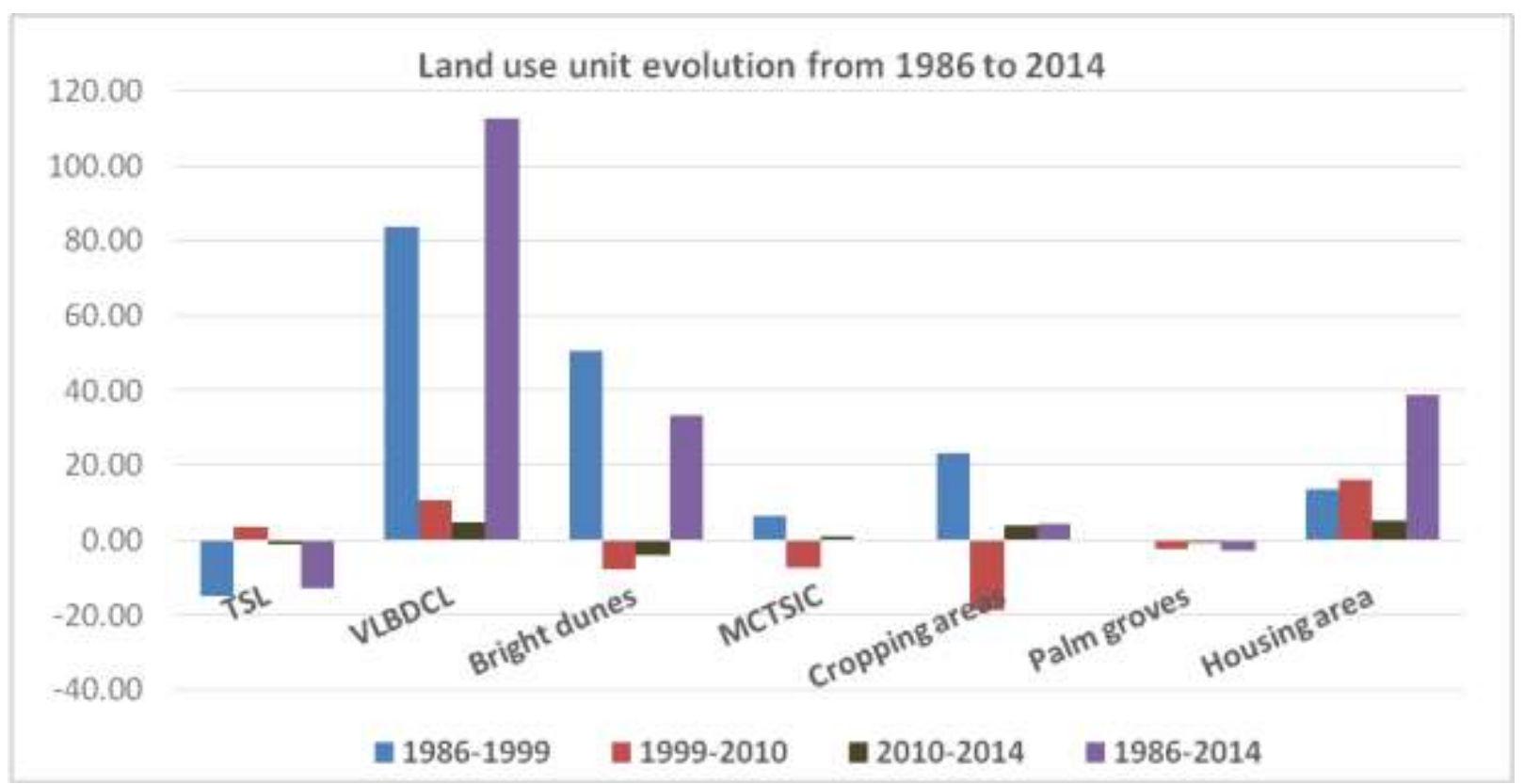

TSL: Trees and/or shrubs by location; VLBDCL: Very little bright dunes covered by location; MCTSIC: Mosaic crops - trees-shrubs of interdunal corridors

Fig.1 Evolution of land use in the study area

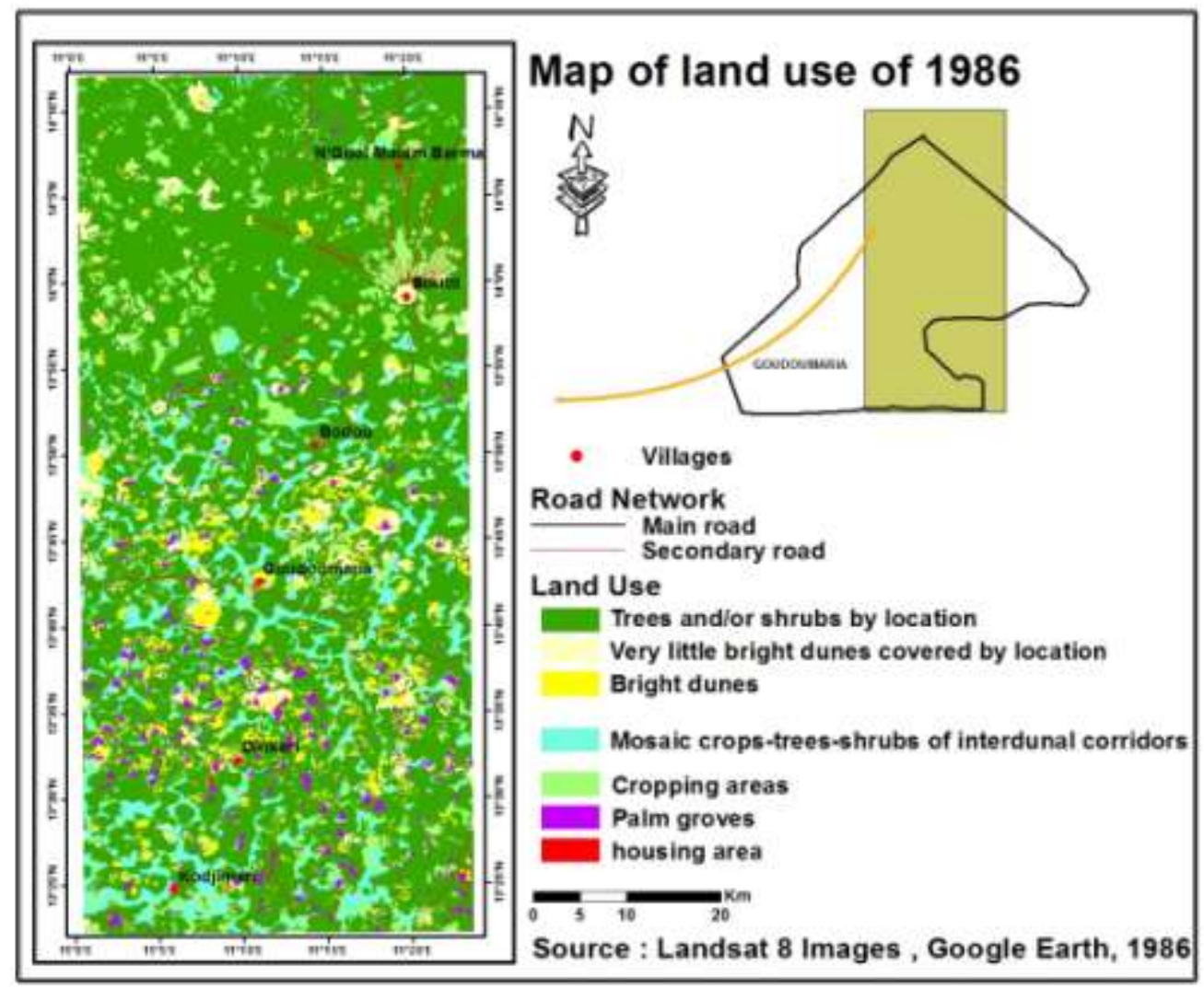

Fig.2 Map of land use of the study area in 1986 


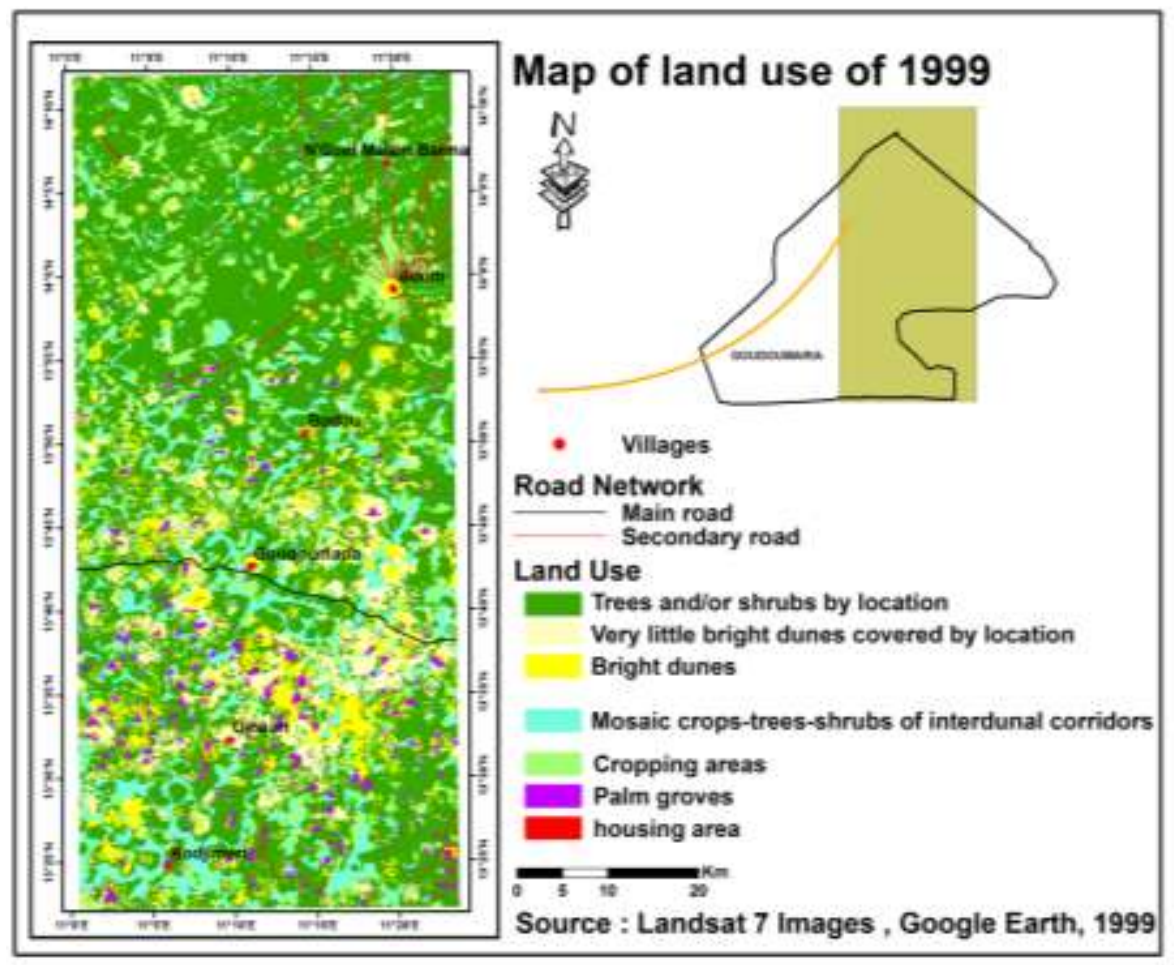

Fig.3 Map of land use of the study area in 1999

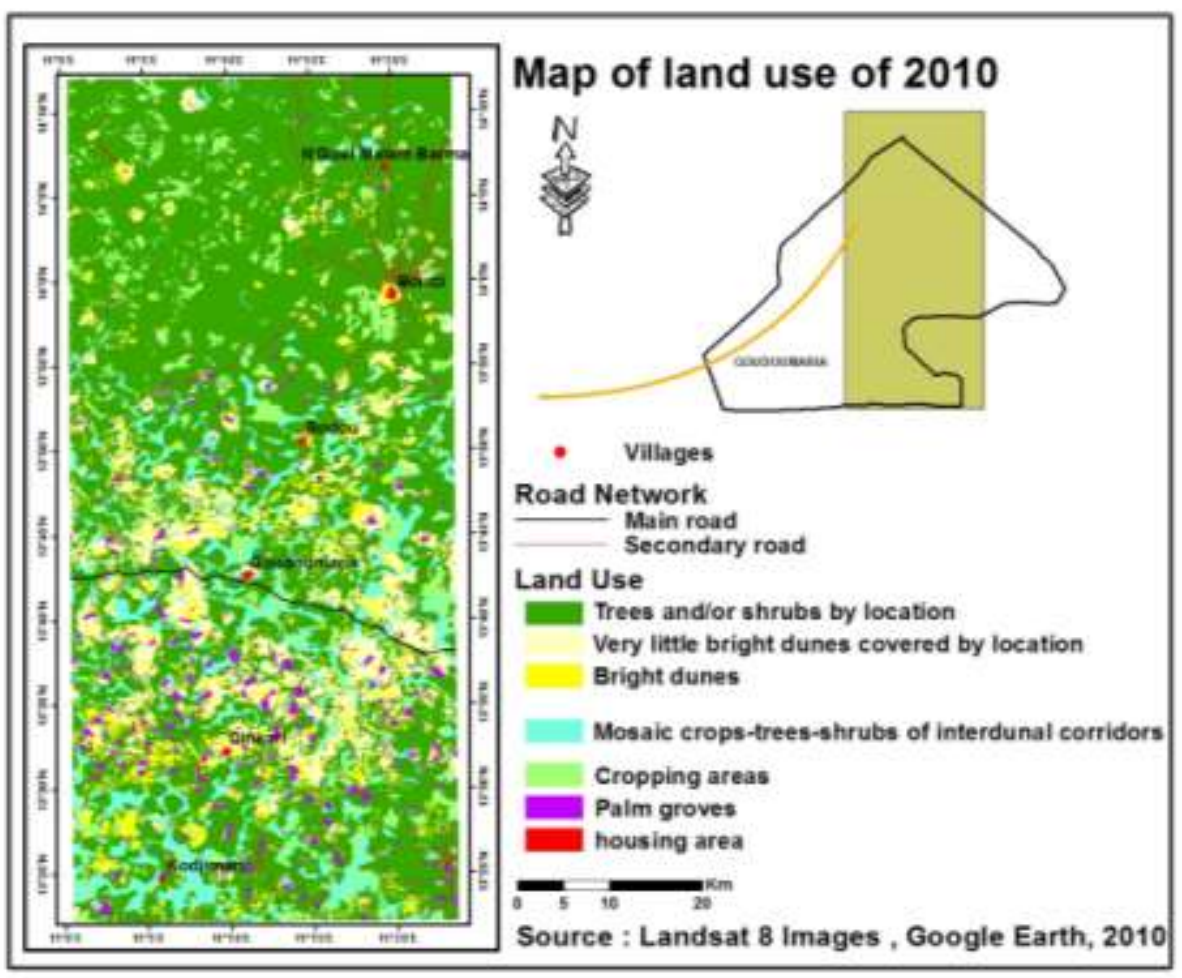

Fig.4 Map of land use of the study area in 2010 


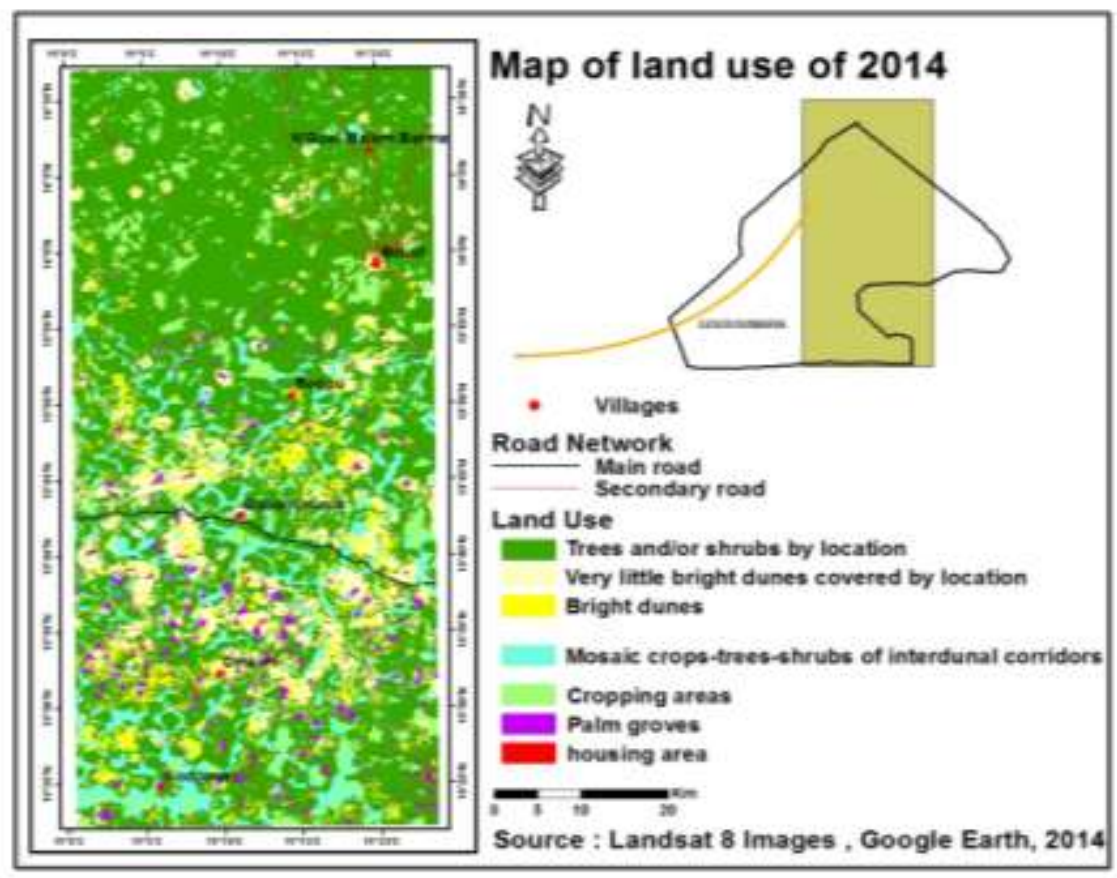

Fig.5 Map of land use of the study area in 2014

Before these events, the areas were more immense because the state of degradation was not yet advanced. Note that other units were almost nonexistent. Thus mobile dunes begin to appear in 1975 in the south, where cultivation areas have been developed (Ado, 2011). But the phenomenon was still insignificant. In 1999, the situation has changed dramatically. Then from 1986 to this period, the area of extension of the steppe has considerably receded.

This can be explained by the progression of degraded units that are the dunes very little covered and the dune alive related to the irregularity of rainfall during these years (the only rainy year 1994 with a total of $554.9 \mathrm{~mm}$ ) and the increase of cultivated area and residential area.

A slight improvement in the condition of stable units will be observed in the 2010 situation. In 2014, a regression of all covered units was observed. Thus, the area occupied by the palm groves or "cuvettes" decreases because of silting in pastoral areas where many of these units are deprived of their vegetation covers and their areas and that of the steppe in the south because of the return to culture after fallow and decrease of trees.

It emerges from this study on the evolution of land use, that these units have regressed through the study of vegetation, soil and water, the perception of the population. There is an adverse change.

\section{Competing interests}

The authors declare that they have no competing interests.

\section{Aknowledgements}

The authors are grateful to the LaSyRe-Sahel Project for sponsoring the first part of field activities.

\section{References}

Ado, S.H., 2011. Occupation des sols, variabilité climatique, dynamique et vulnérabilité des paysages de la limite 
nord des cultures pluviales (commune rurale de Goudoumaria, département de maine soroa, région de diffa, république du Niger», Mémoire de Maitrise, département de géographie, faculté des lettres, Arts et sciences humaines. Université Abdou Moumouni de Niamey. 60 pages.

Ariori, S.L., et Ozer P., 2005. Evolution des ressources forestières en Afrique de l'Ouest soudano-sahélienne au cours des 50 dernières années; Geo-EcoTrop, 2005, 29; pp 61- 68.

Baggnian, I., M.M. Adamou, T. Adam, and Mahamane, A., 2013. Impact des modes de gestion de la régénération naturelle assistée des ligneux (RNA) sur la résilience des écosystèmes dans le Centre-Sud du Niger. Journal of Applied Biosciences, 71, 5742-5752.

Larwanou, M., M. Abdoulaye, and Reij C., 2006. Etude de la régénération naturelle assistée dans la région de Zinder (Niger): Une premiere exploration d'un phénomene spectaculaire. Retrieved from http://www.formad-

environnement.org/RNA_Zinder_usaid .pdf

Ozer, P., Y.C. Hountondji, A.J. Niang, S. Karimoune, O.L. Manzo, and Salmou M., 2010. Désertification au sahel, historique et perspectives, BSGLg, 54, 2010, 69-84.

Projet-MEPRED-Niger, 2007. Rapport sur l'accès aux services énergétiques modernes en vue de contribuer à la réduction de la pauvreté du secteur de l'agriculture, Program intelligent energy, Europe 23 pages.

Wang, C., P.V.D. Meer, M. Peng, W. Douven, R. Hessel, and Dang, C., 2009. Ecosystem Services Assessment of Two Watersheds of Lancang River in Yunnan, China with a Decision Tree Approach. A Journal of the Human Environment 38 (1) (Février 2009) in Royal Swedish Academy of Sciences, pp 47-54.

\section{How to cite this article:}

Ado Salifou Hadiza, Abarchi Idrissa, Ambouta Karimou Harouna and Yamba Boubacar. 2019. Analysis of Land Use of Pastoral and Agropastoral Zone of South East Niger: Case of Goudoumaria. Int.J.Curr.Microbiol.App.Sci. 8(10): 1317-1324.

doi: https://doi.org/10.20546/ijcmas.2019.810.154 